\title{
DURABLE CONSTITUTIONAL RULES AND RENT SEEKING
}

\author{
DANIEL SUTTER
}

University of Oklahoma

\begin{abstract}
Many constitutional political economists argue that the length of time constitutions remain in effect distinguishes constitutional politics from legislative politics. The author explores the role of constitutional durability in a repeated rent-seeking game. A general interest (e.g., consumers) in the game can lobby for a constitutional prohibition that prevents the rent-seeking contest from occurring. A durable constitution can reduce expected rent-seeking expenditures if constitutional politics occurs less frequently than legislative politics, stable rights to receive rents do not exist, and the general interest has a longer time horizon than rent seekers. Under these conditions, general interest lobbying for a constitutional prohibition denies transfers to future rent seekers unable to participate in politics today.
\end{abstract}

Keywords: Rent seeking; constitutional political economy; rent dissipation

\section{INTRODUCTION}

Analysis of the effects of government's redefinition of property rights, the theory of rent seeking, has been a major contribution of public choice scholarship. Rent seeking generates two types of social costs: distortion of economic activity by the transfer and the use of resources in lobbying for or against the transfer. The political force of concentrated benefits and dispersed costs leaves representative democracy vulnerable to the emergence of a "rent-seeking society" (Buchanan, Tollison, and Tullock 1980; Olson 1982).

Constitutional political economy argues that only a change in the rules of the political game can truly reform the rent-seeking society.

AUTHOR'S NOTE: I thank a referee, Tyler Cowen, Robert Florence, Ed Lopez, and Rob Nelson for comments. Earlier drafts of this article were presented at the 2000 Southern Economics Association meetings and the 2001 Public Choice Society meetings.

PUBLIC FINANCE REVIEW, Vol. 31 No. 4, July 2003 413-428

DOI: $10.1177 / 1091142103253786$

(c) 2003 Sage Publications 
Special interest groups take advantage of consumers' and taxpayers' greater collective action and rational ignorance problems to dominate legislative politics. General interest victories in the legislature are likely to be transitory and fleeting. Only constitutional-level limits on the power of government to transfer wealth can avoid negative-sum rent seeking (Buchanan 1987). Yet constitutional rules are themselves the outcome of a political process, and rent-seeking interest groups can employ their significant political ability in constitutional politics. Constitutional economics requires a reason why general interests can prevail over special interests in constitutional politics (Sutter 1995). Constitutional political economists emphasize the durability of constitutional rules (Brennan and Buchanan 1985, 29), which produce two effects. First, citizens have difficulty anticipating specifically how future decisions made under the rules will affect them. Decision making behind the veil of uncertainty is more likely to produce consensus on efficient rules of the game (Brennan and Buchanan 1985, 30-31). Second, infrequent constitutional politics advantages broad, general interests with high costs of organizing for political action (Boudreaux and Pritchard 1993). General interests need only organize for constitutional politics and rely then on the rules of the game to protect their interests in day-to-day politics. ${ }^{1}$

Constitutional rules, however, may not be as durable as constitutional political economists presume. Although the U.S. Constitution has only been amended 27 times in more than 210 years, judicial review of government acts occurs almost every day. Furthermore, the timing of constitutional politics may be endogenous. Constitutional politics may be infrequent only if the constitution already allows wealth transfers. Rent seekers may continually strive to overturn a constitutional prohibition on transfers should one ever pass. Anderson et al. (1990) indeed found that interest groups direct their lobbying efforts to constitutional or legislative action based on the degree of judicial independence in a state. Tollison and Wagner (1991) argued that lobbying by rent seekers to reverse reform will dissipate any potential gains from reform and speculated that a cycle of deregulation and reregulation could even lead to superdissipation of rents. Consequently, the role for constitutional durability in reducing rent-seeking costs is of more than idle interest. 
I explore this question using a two-period extension of a constitutional prohibition rent-seeking model introduced in Sutter (2002). Lobbying by rent seekers and consumers in the first stage determines passage of a constitutional prohibition on transfers. If a prohibition does not pass, the traditional rent-seeking contest (Tullock 1980) ensues to determine establishment of a transfer program. The two-period extension examines the effect of the timing of the constitutional and rent-seeking stages on expected lobbying expenditures. A constitution is durable in the model if the constitutional stage occurs only in Period 1.

I find that constitutional durability is neither a necessary nor a sufficient condition for reducing the social cost of rent seeking. Introduction of a constitutional stage in a rent-seeking model creates a collective action problem among transfer seekers and thus reduces total expected lobbying (Sutter 2002). A durable constitutional prohibition does not, by itself, produce any further reduction in expected lobbying; on the other hand, frequent constitutional politics does not offset the gains due to rent seekers' constitutional free-riding problem either. A durable constitutional prohibition produces additional welfare gains if the constitutional stage occurs only in Period 1, while a rentseeking contest occurs each period, and the Period 2 rent seekers are not also Period 1 rent seekers.

The remainder of this article proceeds as follows. Section 2 presents a two-stage rent-seeking model with a constitutional prohibition on wealth transfers. Section 3 considers a two-period extension of the model with varied timing of the constitutional and legislative stages and demonstrates when rent-seeking costs are reduced compared to the one-period game. Section 4 discusses the plausibility of the conditions under which a reduction in costs of rent seeking occurs. The final section discusses implications of this research for the design of constitutions to control wealth transfers.

\section{THE CONSTITUTIONAL PROHIBITION GAME}

I employ a two-stage constitutional prohibition game. Lobbying in the first stage determines adoption of a constitutional prohibition pre- 
venting a wealth transfer. If the constitutional prohibition fails, the standard rent-seeking game ensues to determine the existence and recipient of the transfer. I ignore issues regarding the form or enforcement of a prohibition to accomplish this goal. The role of the constitutional contest is clear in the model: to prevent the rent-seeking contest. ${ }^{2}$ The constitutional contest does not allocate the rent; it determines only if a rent-seeking contest occurs. So, $n$ rent seekers vie for a transfer exogenously set at $R$. All players are risk neutral. Transfer payers, whom I call the general interest, make defensive expenditures. The general interest bears the transfer plus the deadweight loss from the transfer, $D$. I model the general interest as a single player to maintain tractability, with parameter $\Theta \in(0,1]$ capturing the severity of the general interest's collective action problem. The general interest plays the game for $G=\Theta \bullet(R+D)$; a smaller value of $\Theta$ represents a more severe collective action problem. ${ }^{3}$

Let $x$ and $y_{i}$ be the rent-seeking stage expenditures by the general interest and the $i$ th transfer seeker. I assume that the full amount of all lobbying expenditures at both the legislative and constitutional levels comprises actual resource costs, although the results still hold as long as the same fraction of all lobbying expenditures comprises social costs. I use the widely employed ratio success function for both the rent-seeking and constitutional stages of the game. ${ }^{4}$ The probability that rent seeker $i$ captures the transfer, $\pi_{i}$, is $y_{i} /(Y+x)$ or 0 if $Y+x=0$, where $Y=\Sigma y_{i}$. The total probability of a transfer, $\pi(y, x)$, equals $Y /(Y+x)$. Let $w$ and $z_{i}$ be constitutional stage expenditures by the general interest and the $i$ th rent seeker. The probability of defeat for a prohibition on transfers is $\sigma(w, z)=Z /(Z+w)$ or 0 if $Z+w=0$, where $Z=\Sigma z_{i}$.

I assume that all $n$ rent seekers participate in both the constitutional stage and subsequent rent-seeking contest. ${ }^{5} \mathrm{~A}$ strategy for each player in the constitutional prohibition game is an expenditure pair, $(w, x)$ or $\left(z_{\mathrm{i}}, y_{\mathrm{i}}\right)$. The general interest's utility maximization problem in the twostage game is

$$
\underset{w, x}{\operatorname{Maximize}} \sigma(w, z) \bullet\{-\pi(y, x) \bullet G-x\}-w .
$$

The typical rent seeker solves

$$
\underset{z_{i}, y_{i}}{\operatorname{Maximize}} \sigma(w, z) \bullet\left\{\pi_{i}\left(y_{i}, y_{-i}, x\right) \bullet R-y_{i}\right\}-z_{i} \text {. }
$$


The Nash equilibrium of the constitutional prohibition game is a pair of expenditures for each player. Let a $c$ superscript denote the symmetric equilibrium values for the game. The general interest makes no expenditure in the rent-seeking stage if its stake is sufficiently small, that is, $x^{c}=0$ if $G<G^{*}=(n-1) \bullet R / n$. The general interest in this instance finds resistance to transfers at the legislative stage futile. Equilibrium in the game is as follows:

$$
\begin{array}{ll}
\text { If } G \geq G^{*} & \text { If } G<G^{*} \\
w^{c}=n^{2} \cdot G^{2} \cdot R^{3} \cdot S^{2} /\left[V^{2} \cdot\left(R^{2}+n \cdot G \cdot S\right)^{2}\right] & n^{2} \cdot G^{2} \cdot R /\left(R^{2}+n \cdot G^{2}\right) \\
x^{c}=n \cdot G \cdot R \cdot[n \cdot G-(n-1) \cdot R] / V^{2} & 0 \\
y^{c}=n \cdot G \cdot R^{2} / V^{2} & (n-1) \cdot R / n^{2} \\
z^{c}=G \cdot R^{5} \cdot S /\left[V^{2} \cdot\left(R^{2}+n \bullet G \cdot S\right)\right] & G \cdot R^{2} /\left[n \cdot\left(R+n^{2} \cdot G\right)^{2}\right] \\
\pi^{c}=n \cdot R / V & \\
\sigma^{c}=R^{2} /\left[R^{2}+n \cdot G \cdot S\right] & 1
\end{array}
$$

where $S=2 \cdot n \bullet G-(n-2) \bullet R$ and $V=R+n \bullet G$.

The equilibrium probability of transfers is $\pi^{c} \bullet \sigma^{c}$. Because $\sigma^{c}<1$ even when the general interest finds legislative politics futile $(G<$ $\left.G^{*}\right)$, the constitutional prohibition reduces the likelihood of wealth transfers. The general interest is more likely to prevail in the constitutional contest than in the legislative contest, $\sigma^{c}<\pi^{c}$, for all values of $G$. The general interest's constitutional success stems from rent seekers' collective action problem in constitutional politics-defeating a constitutional prohibition is a public good for rent seekers.

Lobbying efforts comprise a large portion of the costs of rent seeking. Expected lobbying in the constitutional prohibition game is as follows:

$$
E^{c}=n \cdot G \cdot R^{3} \cdot[3 \cdot n \cdot G-(n-3) \cdot R] /\left[V^{2} \bullet\left(R^{2}+n \bullet G \cdot S\right)\right] \text { if } G \geq G^{*},
$$




$$
=R \bullet[n \cdot G+(n-1) \bullet R] /\left[n \bullet\left(R+n^{2} \cdot G\right)\right] \text { if } G<G^{*} .
$$

The constitutional prohibition game adds constitutional lobbying but avoids rent-seeking stage lobbying if a prohibition passes. Despite the apparent ambiguity, Sutter (2002) demonstrated that the constitutional prohibition lowers expected lobbying relative to the traditional rent-seeking game. The general interest takes advantage of rent seekers' constitutional collective action problem to prevent the legislative stage and reduce the cost of the rent-seeking society. I now examine whether a durable constitution produces any further reduction in rentseeking costs in a two-period repeated game extension of this model.

\section{EXTENSION TO A TWO-PERIOD MODEL}

The crucial aspect of the two-period extension concerns the timing of constitutional and legislative politics. Table 1 displays four possible frequencies of the constitutional and rent-seeking stages in the twoperiod model, given that both a constitutional stage and a rent-seeking stage occur in Period $1 .{ }^{6}$ Cases A, B, and C involve a first-period constitutional stage and hence address the issue of constitutional durability, the focus of this article. The last case, D, with a constitutional stage in each period but a rent-seeking stage only in Period 1, may not produce a well-defined game and is not examined here. ${ }^{7}$ Table 1 does not present cases not involving a first-period constitutional contest. Although of relevance for constitutional reform of existing rent seeking, a prohibition adopted in Period 2 lasts a maximum of one period and thus reveals nothing about the role of durability, so I restrict attention to Cases A, B, and C.

Both the constitutional and rent-seeking stages occur each period in Case A. Period i's constitutional stage determines a prohibition on transfers for that period; the succeeding rent-seeking stage allocates only that period's rent. In Case A, constitutional politics occurs as frequently as legislative politics and provides a benchmark for comparison of a durable constitution. The case also considers whether overturning a prohibition can offset the gains from reform, as Tollison and Wagner (1991) suggested. Case B allows constitutional and rentseeking stages only in Period 1. A prohibition adopted in Period 1 can- 
TABLE 1: Timing of Stages in the Two-Period Model

\begin{tabular}{lccccc}
\hline & \multicolumn{2}{c}{ Constitutional Stage } & & \multicolumn{2}{c}{ Rent-Seeking Stage } \\
\cline { 2 - 3 } Case & Period 1 & Period 2 & & Period 1 & Period 2 \\
\hline A & Yes & Yes & & Yes & Yes \\
B & Yes & No & & Yes & No \\
C & Yes & No & & Yes & Yes \\
D & Yes & Yes & & Yes & No \\
\hline
\end{tabular}

not be overturned in Period 2 and thus is durable. But the transfer is noncontestable: The winner of the Period 1 rent-seeking contest receives the rent for both periods. ${ }^{8}$ Constitutional politics occurs as frequently as legislative politics in Case B. Case C involves a constitutional stage that occurs only in Period 1 , whereas a rent-seeking stage occurs each period (provided a prohibition does not pass). The transfer in Case $\mathrm{C}$ is contestable; the successful Period 1 rent seeker faces a challenge from other contenders in Period 2. The Period 1 winner earns no property right to the rent. Often, rents are formally contestable but, in reality, very stable; incumbent firms typically have a significant advantage in "contests" for the renewal of a cable television franchise or television or radio licenses. Sufficient incumbent advantage renders the transfer noncontestable, which is Case B. For simplicity, Case $\mathrm{C}$ considers the limiting instance of no incumbent advantage. Constitutional politics occurs more frequently than legislative politics in Case C.

All participants are fully aware of the timing of each stage in each case. Let $\delta$ be the discount factor and $E^{2}$ be expected lobbying in the two-period model. I compare $E^{2}$ and $(1+\delta) \bullet E^{c}$ : When $E^{2}=(1+\delta) \bullet$ $E^{c}$, the two-period extension has no effect on expected discounted lobbying; if $E^{2}>(<)(1+\delta) \cdot E^{c}$, the multiperiod model strengthens (weakens) the effect of a constitutional prohibition.

Case A merely repeats the model of Section 3. Expected lobbying in each period is $E^{c}$, and the present value of total lobbying is $(1+\delta) \bullet$ $E^{c}$. The welfare gain from a prohibition due to the rent seekers' collective action problem does not depend on the frequency of constitutional politics. A prohibition does not have to be durable to mitigate rent seeking. The multiperiod setting by itself, however, produces no further reduction in lobbying. 
Case B considers a durable prohibition and a noncontestable transfer. Because the Period 1 rent-seeking stage allocates the rent for both periods, the rent seekers play this stage for $(1+\delta) \bullet R$, and the general interest plays for $-(1+\delta) \bullet G$. The equilibrium rent-seeking stage expenditures are just $(1+\delta) \bullet x^{c}$ and $(1+\delta) \bullet y^{c}$. The equilibrium constitutional stage expenditures are then $(1+\delta) \bullet w^{c}$ and $(1+\delta) \bullet z^{c}$, and the present value of expected dissipation is $(1+\delta) \bullet E^{c}$. Mathematically, this result follows because the lobbying function is homogeneous of degree zero and all players are risk neutral. In such a case, ratcheting up the stakes for each side increases both sides' expenditures proportionally and has no effect on the probability outcome. A durable prohibition by itself does not produce a further reduction in lobbying, and a noncontestable rent renders the constitution's durability irrelevant.

Each period's rent-seeking stage contest is as in Section 3 for Case C. The Period 1 rent-seeking stage does not allocate the rent (or a transferable right to the rent) for Period 2. The constitutional stage in this case depends on whether the same $n$ rent seekers participate in each period's rent-seeking contests. The expected value to rent seeker $i$ of participation in a rent-seeking stage is $\pi_{1}^{c} \cdot R-y^{c}$, so a rent seeker who participates in each period's transfer contest has $(1+\delta) \cdot\left[\pi_{i}^{c} \cdot R-y^{c}\right]$ at stake in the constitutional stage. But if different individuals pursue the Period 2 rent, the Period 1 rent seekers have only $\pi_{i}^{c} \cdot R-y^{c}$ at stake in the constitutional stage. The general interest has a net stake of $(1+\delta) \bullet\left[-\pi^{c} \bullet R-x^{c}\right]$ in Period 1's constitutional stage. When the same rent seekers contend for the transfer in each stage, the game is equivalent to $\mathrm{Case} B$, and the present value of expected lobbying is $(1+\delta) \bullet E^{c}$. But with different rent seekers in Period 2 , the equilibrium constitutional stage equilibrium is

$$
\begin{array}{ll}
w^{2}=\frac{(1+\delta)^{2} \cdot n^{2} \bullet G^{2} \bullet R^{3} \bullet S}{V^{2} \cdot\left[R^{2}+(1+\delta) \bullet n \bullet G \bullet S\right]^{2}}, & \text { if } G \geq G^{*} \\
=n^{2} \cdot(1+\delta) \cdot G^{2} \cdot R /\left[R+(1+\delta) \bullet n^{2} \bullet G\right]^{2}, & \text { if } G<G^{*} \\
z^{2}=\frac{(1+\delta) \bullet G \bullet R^{5} \bullet S}{V^{2} \bullet\left[R^{2}+(1+\delta) \bullet n \bullet G \bullet S\right]^{2}}, & \text { if } G \geq G^{*}
\end{array}
$$




$$
\begin{array}{lrl}
=(1+\delta) \cdot G \cdot R^{3} /\left[R+(1+\delta) \cdot n^{2} \cdot G\right]^{2}, & & \text { if } G<G^{*} \\
\sigma^{2}=R^{2} /\left[R^{2}+(1+\delta) \cdot n \bullet G \cdot S\right], & & \text { if } G \geq G^{*} \\
=R /\left[R+(1+\delta) \cdot n^{2} \cdot G\right] . & \text { if } G<G^{*}
\end{array}
$$

The present value of expected lobbying in this case is $E^{2}=n \bullet z^{2}+w^{2}+$ $\sigma^{2} \bullet(1+\delta) \bullet E^{r}$, which equals in equilibrium

$$
\begin{array}{ll}
E^{2}=\frac{(1+\delta) \bullet n \bullet G \bullet R^{3} \bullet[3 \bullet n \bullet G-(n-3) \bullet R]}{V^{2} \bullet\left[R^{2}+(1+\delta) \bullet n \bullet G \bullet S\right]}, & \text { if } G \geq G^{*} \\
=\frac{(1+\delta) \bullet\left[n \bullet G \bullet R+(n-1) \bullet R^{2}\right]}{n \bullet\left[R+(1+\delta) \bullet n^{2} \bullet G\right]} . & \text { if } G<G^{*}
\end{array}
$$

The ratio of stakes in the constitutional stage increases in the general interest's favor when first-period rent seekers cannot capture (either directly or indirectly) second-period rents. This increases the probability of passing a prohibition compared to the one-period game, $\sigma^{2}<\sigma^{c}$, and reduces expected lobbying, as the following result establishes. $^{9}$

Proposition 1. Discounted expected lobbying is lower with a durable constitution and contestable transfers when the second-period rent seekers differ from the first-period rent seekers, $E^{2}<(1+\delta) \cdot E^{c}$.

Proof. I consider first $G \geq G^{*}$, then $G<G^{*}$. In the former case, the difference $(1+\delta) \cdot E^{c}-E^{2}$ is

$\frac{(1+\delta) n G R^{3}[3 n G-(n-3) R]\left\{R^{2}+(1+\delta) n G[2 n G-(n-2) R]-R^{2}-n G[2 n G-(n-2) R]\right\}}{(R+n G)^{2} \bullet\left\{R^{2}+(1+\delta) n G[2 n G-(n-2) R]\right\}\left\{R^{2}+n G[2 n G-(n-2) R]\right\}}$.

This simplifies to

$\frac{(1+\delta) n G R^{3}[3 n G-(n-3) R] \delta n G[2 n G-(n-2) R]}{(R+n G)^{2} \bullet\left\{R^{2}+(1+\delta) n G[2 n G-(n-2) R]\right\}\left\{R^{2}+n G[2 n G-(n-2) R]\right\}}$. 
Because $G \geq G^{*}$, the difference in (13) is positive.

When $G<G^{*}$, the difference $(1+\delta) \bullet E^{c}-E^{2}$ is

$\frac{(1+\delta)\left[n G R+(n-1) R^{2}\right]\left[R+(1+\delta) n^{2} G\right]-(1+\delta)\left[n G R+(n-1) R^{2}\right]\left(R+n^{2} G\right)}{n\left(R+n^{2} G\right)\left[R+(1+\delta) n^{2} G\right]}$.

This simplifies to

$$
\frac{(1+\delta) \cdot\left[n \cdot G \cdot R+(n-1) \cdot R^{2}\right] \cdot \delta \cdot n \cdot G}{n \cdot\left(R+n^{2} \cdot G\right) \cdot\left[R+(1+\delta) \cdot n^{2} \cdot G\right]},
$$

which is clearly positive. QED.

The intuition behind this result is fairly simple; current rent seekers do not receive the second-period transfer, whereas the second-period rent seekers cannot participate in Period 1's constitutional contest. Second-period transfers increase the relative stakes of the constitutional contest for the general interest, increasing the probability a prohibition passes. Second-period rent seekers cannot respond to the general interest's lobbying, so total lobbying expenditures do not simply increase in the constitutional contest, as in Case B.

Proposition 1 establishes only that expected lobbying falls in Case $\mathrm{C}$, not the magnitude of the reduction. Numerical simulations provide some clue here. Set the size of the transfer at $R=10$ and ignore the effects of discounting, $\delta=1$. Table 2 provides the value of expected lobbying in the two-period contest, $E^{2}$, and the ratio of this value to twice the value of expected lobbying from the constitutional prohibition game, $E^{2} /\left(2 \bullet E^{c}\right)$, for values of $n$ ranging from 1 to 10 and values of $G$ from .01 (extreme collective action problems) to 10 (well-organized consumers or an extremely inefficient transfer mechanism). The limiting case of lobbying reduction intuitively is $E^{2} /\left(2 \cdot E^{c}\right)=.5$, which avoids all second-period lobbying costs. The case of $n=10$ reaches this ratio for sufficiently high values of $G$. Examination reveals that the percentage reduction in lobbying costs increases as $n$ increases for a given $G$ and as $G$ increases for a given $n$. Note, however, that expected lobbying is already low when $n=10$, so a larger absolute reduction in expected lobbying occurs for smaller values of $n$. The constitu- 
TABLE 2: Potential Reduction in Expected Lobbying

\begin{tabular}{|c|c|c|c|c|c|c|c|c|}
\hline \multirow[b]{2}{*}{$\mathrm{G}$} & \multicolumn{2}{|c|}{$\mathrm{n}=1$} & \multicolumn{2}{|c|}{$\mathrm{n}=2$} & \multicolumn{2}{|c|}{$\mathrm{n}=5$} & \multicolumn{2}{|c|}{$\mathrm{n}=10$} \\
\hline & $E^{2}$ & $\mathrm{E}^{2} / 2 \cdot \mathrm{E}^{\mathrm{c}}$ & $E^{2}$ & $E^{2} / 2 \cdot E^{c}$ & $E^{2}$ & $E^{2} / 2 \cdot E^{c}$ & $E^{2}$ & $E^{2} / 2 \cdot E^{c}$ \\
\hline 10 & 4.10 & 0.66 & 1.83 & 0.53 & 0.51 & 0.51 & 0.16 & 0.50 \\
\hline 8 & 4.21 & 0.60 & 2.44 & 0.55 & 0.78 & 0.51 & 0.21 & 0.50 \\
\hline 6 & 4.89 & 0.64 & 5.67 & 0.96 & 0.90 & 0.51 & 0.25 & 0.50 \\
\hline 4 & 5.35 & 0.70 & 6.92 & 0.99 & 1.14 & 0.52 & 0.32 & 0.50 \\
\hline 1 & 3.07 & 0.90 & 8.57 & 1.0 & 3.00 & 0.58 & 0.95 & 0.52 \\
\hline .1 & 0.39 & 0.98 & 9.81 & 1.0 & 10.8 & 0.83 & 6.07 & 0.61 \\
\hline .01 & 0.04 & 1.0 & 9.98 & 1.0 & 15.3 & 0.98 & 15.0 & 0.92 \\
\hline
\end{tabular}

tional stage allows the general interest to exploit rent seekers' collective action problem; removing the value of Period 2 rents strengthens the general interest's relative advantage.

\section{DISCUSSION}

My analysis has identified conditions under which a durable constitution reduces the costs of rent seeking beyond the level resulting from the rent seekers' free rider problem in overturning a prohibition. The constitution must be durable, the transfer must be contestable, and the set of rent seekers must turn over between periods. I discuss in this section the plausibility of these three conditions.

Durability in this model does not strictly mean the length of time the constitution remains unaltered. Rather, durability refers to the infrequency of constitutional politics. Suppose a constitutional prohibition enacted in Period 1 is challenged but not overturned in Period 2. Such a prohibition remains in effect for two periods, yet constitutional politics is frequent, and this example does not qualify for Case $\mathrm{C}$. The relevant question becomes whether constitutional politics is truly infrequent, and this is more difficult to address than the length of time a constitutional provision remains in place. Evidence based on the duration of rules does not address the frequency of efforts to change the rules. Arguably, every court challenge of the constitutionality of a law and each proposed constitutional amendment introduced in Congress represent a constitutional stage game. Clearly, these can occur fre- 
quently. Several provisions restricting wealth transfers, such as the contracts clause, the interstate commerce clause, and the Fifth Amendment's prohibition on takings, have remained in place for more than 200 years, but their meaning has been changed by judicial interpretation over the years (Siegan 1980). The force of precedent in constitutional law serves to make judicial challenges less frequent; once the Supreme Court has ruled on a question, little incentive exists to mount a new challenge until the composition of the Court changes.

Transfers must be contestable to prevent capitalization of secondperiod rents into the Period 1 contest (McCormick, Shughart, and Tollison 1984); first-period rent seekers would then take this capitalized rent into account in constitutional lobbying. The contestability of rents is an empirical matter. Crew and Rowley (1988) argued persuasively that rents are generally contestable. A current government cannot prevent a future regime from transferring a rent from an incumbent to a challenger. Time consistency is a serious problem in political economy precisely because governments cannot generally commit over time.

Finally, Period 1 rent seekers must not value second-period rents. A contestable transfer is not sufficient for this. If the same set of rent seekers contends each period, rent seekers consider the value of participation in the second contest in constitutional lobbying. The set of rent seekers must turn over between periods. Turnover depends on barriers to entry into rent seeking; high barriers to entry produce little turnover of rent seekers. Another factor is whether rights to participate in rent seeking can be transferred. In this case, the identity of the actual rent seekers might change, but a rent seeker could sell the participation right at the end of one period, so the Period 2 rents still enter the constitutional stage calculation. Turnover would occur if the number of potential rent seekers exceeds $n$ and a cost of participation limits any one contest to $n$ active participants. Any one potential rent seeker would be unlikely to participate in both contests. A landed aristocracy whereby nobles contend for favors from the royal court represents a case in which turnover is unlikely. The court favorite may be determined period by period, so royal prerogative ensures a contestable transfer. But the nobles would recognize the value of participation in future contests. Democracy approximates the conditions for turnover-all citi- 
zens possess participation rights, and the barriers to entry in rent seeking are low.

A difference in discount factors might also prevent the secondperiod transfer from entering into Period 1 rent seekers' calculations. The veil of uncertainty can produce this effect. Suppose the two periods in the model are distant in time, perhaps corresponding to successive generations. Citizens behind the veil do not know if they will be on the paying or receiving end of transfers and hence have an incentive to choose constitutional rules restricting government's power to transfer wealth (Brennan and Buchanan 1985). If the identity of secondperiod rent seekers is unknown at the start of Period 1 and the transfer is contestable, the second-period rent is eliminated from consideration in the constitutional contest. ${ }^{10}$

\section{DURABILITY AND CONSTITUTIONAL DESIGN}

A long-lasting constitution by itself does not reduce the costs of rent seeking, but durability can make a contribution. I conclude by considering the implications of my analysis for the design of a constitution to limit the costs of transfer seeking.

Constitutional politics must occur infrequently, and precedent in constitutional law serves this end. A constitution could directly regulate judicial review, mandating a minimum waiting period for rearguing a decision, and thus strengthen precedent in making constitutional politics infrequent. Similar regulation of the amendment process would impose a minimum waiting period for reconsideration of a failed amendment or attempt to repeal an amendment. Finally, provisions limiting government's powers to transfer wealth could be made unamendable, requiring future constitutional politics to involve overturning the constitution.

The constitution could also undermine the stability of rights to rents. The U.S. Constitution prohibits the current Congress from binding a future Congress, thus limiting the ability of government to make long-term contracts. Separation of powers and an independent judiciary also undermine the stability of government deals. Constitutional economists continue to debate the actual degree of judicial independ- 
ence. ${ }^{11}$ Even if the judiciary does not routinely overturn legislative deals, the potential exists, introducing risk and reducing the expected value of rents won today. ${ }^{12}$

The constitution should also keep barriers to entry for future rentseeking contests as low as possible-in particular, avoiding rights to seek government favors. Elaborate procedures for bidding on government contracts and reducing the number of contenders for rents have an effect similar to rent-seeking rights. The value of future contracts will be capitalized in a privileged bidder's current stock price. Limits on participation in contests or subsequent bidding after winning (term limits on receiving rent) increase turnover of rent seekers. Note the contrast with Tullock (1980) on the role of barriers to entry. A small and stable number of contenders in the rent-seeking contest limit lobbying. Yet the prospect of competition from future contenders creates an intertemporal public goods problem for rent seekers and increases the probability of passing a prohibition on transfers today. Social welfare rises if the welfare of future generations of rent seekers is ignored in today's constitutional contest.

\section{NOTES}

1. Ackerman (1991) similarly discussed U.S. constitutional history in terms of constitutional "moments" in which "the people" (a general interest) altered the rules of the game in accordance with their evolving preferences.

2. I do not claim that all constitutional provisions are designed to counter rent seeking. Certainly, some provisions, such as the 16th Amendment allowing the income tax, have facilitated rent seeking.

3. Public good rent-seeking models (Katz, Nitzan, and Rosenberg 1990; Nitzan 1991) explicitly model contributions to the general interest. My approach allows generality because I need not assume a specific distribution of the transfer's costs or rule out employment of a technology of cooperation.

4. Papers employing the ratio function include Tullock (1980), Hillman and Katz (1984), Baron (1989), and Fabella (1995).

5. Alternatively, some rent seekers might not participate in the constitutional contest altogether, but total lobbying expenditures remain unchanged as the number of active rent seekers changes (Katz, Nitzan, and Rosenberg 1990; Sutter 2002).

6. Occurrence of the rent-seeking stage is always contingent on the outcome of the constitutional stage.

7. Suppose a prohibition passes in Period 1 , so the rent-seeking contest does not occur. If the prohibition is overturned in Period 2, no rent-seeking game follows in this case. 
8. A noncontestable transfer creates a stable property right for Period 2's transfer. The Period 1 rent seeker can sell this right if he or she wishes, as with a taxicab medallion.

9. Welfare gains exceed the reduction in lobbying expenditures because of the reduced probability of the inefficiency cost of transfers.

10. A sufficiently thick veil of uncertainty ensures that no one knows if he or she will be a rent seeker during the constitutional stage.

11. Landes and Posner (1975) argued that the "independent" judiciary actually serves as an agent of the legislature, upholding prior legislative deals against the current government. For a dissenting view, see Boudreaux and Pritchard (1994).

12. The current model assumes that the winner of the rent-seeking contest merely receives a transfer. If the transfer involves use of a durable asset (e.g., mining or logging rights on public land), short-term rights discourage conservation of the resource to maximize its lifetime value.

\section{REFERENCES}

Ackerman, B. 1991. We the people: Vol. 1. Foundations. Cambridge, MA: Harvard University Press.

Anderson, G. M., D. T. Martin, W. F. Shughart II, and R. D. Tollison. 1990. Behind the veil: The political economy of constitutional change. In Predicting politics, edited by W. M. Crain and R. D. Tollison, 89-100. Ann Arbor: University of Michigan Press.

Baron, D. 1989. Service-induced campaign contributions and the electoral equilibrium. Quarterly Journal of Economics 104 (1): 45-72.

Boudreaux, D. J., and A. C. Pritchard. 1993. Rewriting the Constitution: An economic analysis of the constitutional amendment process. Fordham Law Review 62:111-62.

. 1994. Reassessing the role of the independent judiciary in enforcing interest-group bargains. Constitutional Political Economy 5:1-21.

Brennan, G., and J. M. Buchanan. 1985. The reason of rules. Cambridge, UK: Cambridge University Press.

Buchanan, J. M. 1987. The constitution of economic policy. American Economic Review 77 (3): 243-50.

Buchanan, J. M., R. D. Tollison, and G. Tullock, eds. 1980. Toward a theory of the rent seeking society. College Station: Texas A\&M Press.

Crew, M. A., and C. K. Rowley. 1988. Dispelling the disinterest in deregulation. In The political economy of rent-seeking, edited by C. K. Rowley, R. D. Tollison, and G. Tullock, 163-78. Boston: Kluwer Academic.

Fabella, R. V. 1995. The social cost of rent seeking under countervailing opposition to distortionary transfers. Journal of Public Economics 57:235-47.

Hillman, A. L., and E. Katz. 1984. Risk-averse rent seekers and the social cost of monopoly power. Economic Journal 94:104-10.

Katz, E., S. Nitzan, and J. Rosenberg. 1990. Rent-seeking for pure public goods. Public Choice 65:49-60.

Landes, W. M., and R. A. Posner. 1975. The independent judiciary in an interest-group perspective. Journal of Law and Economics 18:875-901.

McCormick, R. E., W. F. Shughart II, and R. D. Tollison. 1984. The disinterest in deregulation. American Economic Review 74 (5): 1075-79. 
Nitzan, S. 1991. Collective rent dissipation. Economic Journal 101:1522-34.

Olson, M. 1982. The rise and decline of nations. New Haven, CT: Yale University Press. Siegan, B. 1980. Economic liberties and the Constitution. Chicago: University of Chicago Press. Sutter, D. 1995. Constitutional politics within the interest-group model. Constitutional Political Economy 6:127-37.

. 2002. Constitutional prohibitions in a rent seeking model. Public Choice 111:105-25.

Tollison, R. D., and R. E. Wagner. 1991. Romance, realism, and economic reform. Kyklos 44 (1): 57-70.

Tullock, G. 1980. Efficient rent seeking. In Toward a theory of the rent seeking society, edited by J. M. Buchanan, R. D. Tollison, and G. Tullock, 97-112. College Station: Texas A\&M Press.

Daniel Sutter is a graduate of George Mason University. His fields of specialization include public choice, public finance, and regulation, and his current research explores constitutional political economy and the economics of the news media. He has published articles previously in Economic Inquiry, the Southern Economics Journal, Public Choice, Economics and Politics, and the Journal of Economic Behavior and Organization. 